\title{
CHARACTERIZATION AND IDENTIFICATION OF THE BEST SCREENED INDIGENOUS LACTIC ACID BACTERIA PRODUCING $\beta$-GALACTOSIDASE
}

\author{
Tatik Khusniati, ${ }^{1 *}$ Agustina Tri Aditya,${ }^{2}$ Abdul Choliq ${ }^{1}$ and Sulistiani ${ }^{1}$ \\ 1. Microbiology Division, Research Center for Biology, \\ Indonesian Institute of Sciences \\ 2. High School of Industrial Technology and Pharmacy, Bogor \\ * correspondence author: tatikkhusni@yahoo.com
}

\begin{abstract}
$\beta$-Galactosidase (EC 3.2.1.23) is an enzyme used in production of low/free lactose milk consumed mainly human which have lactose intolerance. Characteristics of indigenous Lactic acid bacteria (LAB) producing $\beta$-galactosidase haven't been fully reported. To know the characteristics of the $L A B$, characterization and identification of the best screened indigenous $L A B$ producing $\beta$-galactosidase were researched. The best $L A B$ was molecularly identified. The crude $\beta$-galactosidase of $L A B$ was produced by centrifugation. The optimum production of the best LAB b-galactosidase was measured based on incubation time, inoculum concentration, $\mathrm{pH}$ and lactose concentration. The optimum activity of the $\beta$-galactosidase was measured based on $\mathrm{pH}$ and temperature. The $\beta$-galactosidase activity was measured by modified method of Lu et al., 2009. Research results show that 10 (ten) out of 70 (seventy) indigenous LAB produced $\beta$-galactosidase with high activities. $L A B$ producing the highest $\beta$-galactosidase activity than the others was LAB strain B110. The LAB strain B110 was identified molecularly as Lactobacillus plantarum strain B110. The $\beta$-galactosidase optimum production of $L$. plantarum strain B110 was reached at incubation time for 30 hours, $2 \%$ inoculum concentration, medium $\mathrm{pH}: 7$, and $2 \%$ lactose concentration. The optimum activity of the $\beta$-galactosidase was reached at temperature of $45^{\circ} \mathrm{C}$ and $\mathrm{pH}: 6,5$, respectively. Based on selection and characterization of $L$. plantarum strain B 110, L. plantarum strain B 110 was the best $L A B$ producing $\beta$-galactosidase than that of the other $L A B$.
\end{abstract}

Key words: characterization, identification, Lactic Acid Bacteria, $\beta$-galactosidase, indigenous

\section{INTRODUCTION}

$\beta$-Galactosidase (EC 3.2.1.23) is an enzyme used in production of low/free lactose milk consumed mainly human which have lactose intolerance. The $\beta$-galactosidase is enzyme hydrolyzing lactose to be glucose and galactose (Chakraborti et al., 2000; Rhimi et al., 2009; Chen et al., 2008). This enzyme was found from various types of bacteria (Li et al., 2009), such as: probiotic bacteria (Hsu et al., 2005), lactic acid bacteria (Jokar \& Karbassi, 2011; Mozumder et al., 2012), and Enterobacter cloacae B5 (Lu et al., 2009). Beside, this enzyme can be consumed by milk consumers which have "lactosa intolerance in the form of suplement or beverage of low/free lactose milk (Britz \& Robinson, 2008; Guzec et al., 2008).

Various types and species of bacteria were reported to contain $\beta$-galactosidase (Jokar \& Karbassi, 2011; Li et al., 2009, Mozumder et al., 2012). Furthermore, the difference in character of $\beta$-galactosidase may have resulted from the difference in type and spesies of bacteria producing $\beta$-galactosidase. Moreover, it was estimated that the different optimum condition of $\beta$-galactosidase (enzyme activity, temperature and $\mathrm{pH}$ ) may have resulted from the difference in character of $\beta$-galactosidase from the different bacteria. It has been reported that there were the different optimum condition of $\beta$-galactosidase activites 
between the different type of microorganism (Bai \& Elledge, 1996; Hsu et al., 2005; Li et al., 2009;).

The various indigenous lactic acid bacteria producing $\beta$-galactosidase were screened to get the best indigenous lactic acid bacteria producing $\beta$-galactosidase. The characterization of the best indigenous lactic acid bacteria producing $\beta$-galactosidase haven't been reported, To know the characterization of the best lactic acid bacteria, characterization and identification of the best screeneed indigenous lactic acid bacteria producing $\beta$-galactosidase were reserached.

\section{MATERIALS AND METHODS}

The growth media of indigenous Lactic Acid Bacteria (LAB)

The growth media of indigenous Lactic Acid Bacteria (LAB) used was 20 g glucose, $10 \mathrm{~g}$ pepton, $8 \mathrm{~g}$ beef extract, $5 \mathrm{~g} \mathrm{Na}$ acetic $3 \mathrm{H}_{2} \mathrm{O}, 4 \mathrm{~g}$ yeast extract, $2 \mathrm{~g} \mathrm{~K} \mathrm{~K}_{2} \mathrm{HPO}_{4}, 2 \mathrm{~g}$ triamonium citrate, $0,2 \mathrm{~g} \mathrm{MgSO}_{4} 7 \mathrm{H}_{2} \mathrm{O}, 0,05 \mathrm{~g} \mathrm{MnSO}_{4} \cdot 4 \mathrm{H}_{2} \mathrm{O}, 1 \mathrm{ml}$ tween $80,10 \mathrm{~g} \mathrm{NaCl}, 10$ $\mathrm{g} \mathrm{CaCO}_{3}$, soluted into $1000 \mathrm{ml}$ aquadest and measured $\mathrm{pH}$ up to 7 , and it was then heated and added bacto agar $20 \mathrm{~g}$. The solution was heated up to homogenous, and sterilized at temperature $121^{\circ} \mathrm{C}$ for 15 minutes. The solution was then poured in sterilized petridish.

\section{Purification of the LAB producing b-galactosidase}

The LAB producing $\beta$-galactosidase was purified by using 1 ose of LAB cultured in MRS agar media and it was streaked and incubated. Colony of LAB was purified by streak method by using 1 ose of LAB colony streaked into MRS agar media, and it was incubated in room temperature. One (1) ose of purified LAB colonyi was taken and streaked in slant MRS agar.

\section{Selection of the LAB producing $\beta$-galactosidase}

The LAB producing $\beta$-galactosidase was selected by using $1000 \mu$ ONPG and 1 ose of $L A B$ poured into microtiter plate. $L A B$ suspension was then incubated for 48 hours at temperature $37^{\circ} \mathrm{C}$. After incubation, $800 \mu \mathrm{LAB}$ suspension was poured into microtube and centrifuged. The $500 \mu \mathrm{l}$ supernatant resulted was added $2500 \mu \mathrm{Na}_{2} \mathrm{CO}_{3} 1 \mathrm{M}$ and it was then analyzed by spectrophotometer UV-VIS at $\lambda 420 \mathrm{~nm}$ (modified Lapage et al., 1973).

\section{Identification of the best screened indigenous LAB (modified Mahenthiralingam et al, 2009)}

The best screened indigenous $L A B$ was molecularly identified. The molecularly identification of the LAB was conducted by amplification of 16S rDNA bacteria sequen area. The amplification was conducted by colony method of PCR. The amplification process used primer 27F 5'-AGAGTTTGATCCTGGCTCAG-3' dan primer 1492R 5'GGTTACCTTGTTACGACTT-3'. PCR product was visualized by electrophoresis and documented by gel documentation system. PCR product was then purified and cycle sequenced by $27 \mathrm{~F}$ primer. Product of cycle seqencing was purified and denaturated by Hi Di formamide and injected to 3730xI DNA analyzer (www.macrogen.com). 


\section{Production of the LAB $\beta$-galactosidase}

Production of the LAB $\beta$-galactosidase was conducted by using $2 \%$ LAB inoculum wth OD: 0.7 at $\lambda 600 \mathrm{~nm}$ inoculated into $900 \mathrm{ml}$ MRS media sterilized and it was incubated for 48 hours at temperature $37^{\circ} \mathrm{C}$. Cell culture was centrifuged at $9500 \mathrm{rpm}$ for 15 minutes at temperature $4^{\circ} \mathrm{C}$. Pellet found was washed twice by buffer phosphate $0,05 \mathrm{M} \mathrm{pH} 6,5$. Every 1 gram pellet found was soluted into $5 \mathrm{ml}$ buffer phosphate $0,05 \mathrm{M} \mathrm{pH} 6,5$, and the cell was broken by sonicator for 5 minutes at temperature $4^{\circ} \mathrm{C}$. The suspension was centrifuged at $9500 \mathrm{rpm}$ for 15 minutes at temperature $4^{\circ} \mathrm{C}$. Supernatan found was $\beta$-galactosidase enzyme (Wang \& Sakakibara, 1997).

\section{Activity of the LAB $\beta$-Galacosidase}

Activity of the LAB $\beta$-galactosidase was measured by using $1000 \mu$ l bufer phosphate $0,1 \mathrm{M} \mathrm{pH} 7$ and $100 \mu \mathrm{l}$ enzyme poured into reaction tube and it was incubated at temperature $37^{\circ} \mathrm{C}$ for 5 minutes. It was then added $200 \mu$ o-Nitrofenil- $\beta$-D-galaktopiranosida (ONPG) $4 \mathrm{mg} / \mathrm{ml}$ and incubated at temperature $37^{\circ} \mathrm{C}$ for 15 minutes. At minute of 15 , it was added $1000 \mu \mathrm{Na}_{2} \mathrm{CO}_{3} 1 \mathrm{M}$. The solution was analyzed by using spectrophotometer UV-VIS at $\lambda$ $420 \mathrm{~nm}$. The enzyme activity (U/ml) was defined as the amount of $\mu \mathrm{mol}$ o-nitrofenol (ONP) formed per minute per mililiter enzyme at treatment condition (modified Lu et al., 2009).

$$
\operatorname{Activity}(\mathrm{U} / \mathrm{ml})=\frac{\text { mikromol onp }}{(\mathrm{V} \times \mathrm{t})}
$$

Note: $\mathrm{V}$ : volume enzyme tested $(\mathrm{ml})$, t: incubation time (minute)

\section{The growth optimum of the $L A B$ producing $\beta$-galactosidase.}

The growth optimum of LAB producing $\beta$-galactosidase was based on the optimum of incubation time, inoculum concentration, medium $\mathrm{pH}$, and lactose concentration. The incubation times used were $6,12,24,30,36,42$, and 48 hours, and the inoculum concentrations were $1 \%, 2 \%$, and $5 \%$. The $\mathrm{pH}$ used were $5,5,5,6,0,6,5,7,0,7,5$ and 8,0 ., and the lactose concentrations were $1 \%, 2 \%$, and $3 \%$. The optimum production of LAB $\beta$-galactosidase was the highest $\beta$-galactosidase activity in the certain condition of incubation time, inoculum concentration, medium $\mathrm{pH}$ and lactose concentration used in the growth of $\mathrm{LAB}$.

\section{The optimum activity of â-galacosidase}

The optimum activity of $\beta$-galacosidase was based on the optimum of temperature and $\mathrm{pH}$. The temperatures used were $25,30,35,40,45,50$, and $55^{\circ} \mathrm{C}$, and the $\mathrm{pH}$ were $5,6,7$, and 8 . The optimum activity of $L A B$ â-galactosidase was the highest $\beta$-galactosidase activity in the certain temperature and pH (modified Marteu et al., 1990).

\section{RESULTS AND DISCUSSION}

Research results showed that 10 (ten) out of 70 (seventy) indigenous LAB produced $\beta$ galactosidase with high activities. $L A B$ producing the highest â-galactosidase activity than the others was $L A B$ strain B110 (Table 1). The $\beta$-galactosidase activity of LAB strain B110 
was $1.930 \mathrm{U} / \mathrm{mL}$, while the $\beta$-galactosidase activities of the other LAB strains were in the range $0.219-1.864 \mathrm{U} / \mathrm{mL}$ (Table 1). The $\beta$-galactosidase activities were affected by the type and species of the bacteria producing $\beta$-galactosidase. It has been reported that the differences in type and species of bacteria producing â-galactosidase may have resulted in the differences in $\beta$-galactosidase activities resulted (Hsu et al., 2005; Li et al., 2009; Lu et al., 2009)

Table 1. The $\beta$-galactosidase activities of the 10 screened indigenous LAB.

\begin{tabular}{cccc}
\hline LAB Isolates & $\mathrm{A}_{\text {bsorbance }}$ & $\mu$ mol ONP & Activity $(\mathrm{U} / \mathrm{mL})$ \\
\hline SB40 & 0.294 & 2.796 & 1.864 \\
B134 & 0.227 & 2.170 & 1.447 \\
B121 & 0.226 & 2.161 & 1.440 \\
SC35 & 0.030 & 0.329 & 0.219 \\
B116 & 0.132 & 1.282 & 0.855 \\
B135 & 0.295 & 2.806 & 1.870 \\
SC39 & 0.252 & 2.399 & 1.599 \\
B112 & 0.266 & 2.530 & 1.687 \\
B110 & $\mathbf{0 . 3 0 5}$ & $\mathbf{2 . 8 9 4}$ & $\mathbf{1 . 9 3 0}$ \\
B132 & 0.212 & 2.030 & 1.353 \\
\hline
\end{tabular}

The identification result of the best screened indigenous LAB showed that based on molecular identification using amplification of $16 \mathrm{~S}$ rDNA sequen area, data resulted from sequencing trimmed by BioEdit program and converted in the form of FASTA format, and the result of DNA sequencing in the form of FASTA format blasted to look for homology in on line in the center of DNA data base in NCBI (http://www.ncbi.nlm.nlh.gov/), the best screened indigenous LAB-B110 was identified as Lactobacillus plantarum. The length of DNA sequen in partial analysis of $16 \mathrm{~S}$ rDNA was $788 \mathrm{bp}$. Homology of BLAST in NCBI with max identity: $100 \%$, max score 1422 , total score 1422 , query coverage $100 \%$, E value 0,0 to taxson of closed bacteria. Mahenthiralingan et al. (2009) reported that molecularly identification produced identification in species level.

The optimum $\beta$-galactosidase production of $L$. plantarum strain B110 was reached at incubation time for 30 hours, $2 \%$ inoculum concentration, medium $\mathrm{pH}: 7$, and $2 \%$ lactose concentration (Table 2-3). The optimum $\beta$-galactosidase activity at 30 hours incubation time was $0.472 \mathrm{U} / \mathrm{mL}$ (Table 2), the optimum activity at $2 \%$ inoculum concentration was $3.553 \%$, the activity at medium $\mathrm{pH}: 7$ was $1.815 \mathrm{U} / \mathrm{mL}$, and the activity at $2 \%$ lactose concentration was $14.964 \mathrm{U} / \mathrm{mL}$ (Table 3 ). The $\beta$-galactosidase activities were affected by the growth condition of the bacteria producing $\beta$-galactosidase. It has been reported that the differences in the growth condition of bacteria producing $\beta$-galactosidase may have resulted in the differences in $\beta$-galactosidase activities resulted (Hsu et al., 2005; Li et al., 2009; Lu et al., 2009).

The optimum activity of the $\beta$-galactosidase of $L$. plantarum strain $B-110$ was reached at temperature of $45^{\circ} \mathrm{C}$ and $\mathrm{pH}: 6,5$, respectively (Figure 1-2). The optimum $\beta$-galactosidase activity of $L$. plantarum strain B-110 at temperature of $45^{\circ} \mathrm{C}$ was $695 \mathrm{U} / \mathrm{mL}$, while the optimum of the $\beta$-galactosidase activity at $\mathrm{pH} 6.5$ was $535 \mathrm{U} / \mathrm{mL}$. The optimum $\beta$-galactosidase activities were affected by the type and species of the bacteria producing $\beta$-galactosi- 
dase. It has been reported that the differences in type and species of bacteria producing $\beta$ galactosidase may have resulted in the differences in $\beta$-galactosidase activities resulted (Chakraborti et al., 2000; Hsu et al., 2005; Li et al., 2009).

Table 2. The $\beta$-galactosidase activities of $L$. plantarum strain B-110 in various incubation times

\begin{tabular}{cccc}
\hline Hour & Absorbance & $\mu$ mol ONP & Activity $(\mathrm{U} / \mathrm{ml})$ \\
\hline 0 & 0.000 & 0.000 & 0.000 \\
6 & 0.190 & 0.009 & 0.009 \\
12 & 0.178 & 0.078 & 0.078 \\
18 & 0.251 & 0.151 & 0.151 \\
24 & 0.228 & 0.128 & 0.255 \\
$\mathbf{3 0}$ & $\mathbf{0 . 5 7 2}$ & $\mathbf{0 . 4 7 2}$ & $\mathbf{0 . 4 7 2}$ \\
36 & 0.297 & 0.197 & 0.393 \\
42 & 0.172 & 0.072 & 0.143 \\
\hline
\end{tabular}

Table 3. The $\beta$-galactosidase activities of $L$. plantarum strain $B 110$ in various inoculum, $\mathrm{pH}$ and lactose concentration

\begin{tabular}{lcccc}
\hline \multicolumn{2}{c}{ Treatment } & $\mathrm{A}_{\text {bsorbance }}$ & $\mu$ mol ONP & Activity $(\mathrm{U} / \mathrm{mL})$ \\
\hline Inoculum & $1 \%$ & $0 ., 235$ & 2.240 & 2.240 \\
concentration & $\mathbf{2 \%}$ & $\mathbf{0 . 3 7 5}$ & $\mathbf{3 . 5 5 3}$ & $\mathbf{3 . 5 5 3}$ \\
& $5 \%$ & 0.240 & 2.292 & 2.292 \\
\hline $\mathrm{pH}$ & $\mathrm{pH} \mathrm{5}$ & 0.123 & 1.198 & 1.198 \\
& $\mathrm{pH} \mathrm{6}$ & 0.154 & 1.488 & 1.488 \\
& $\mathbf{p H ~ 7}$ & $\mathbf{0 . 1 8 9}$ & $\mathbf{1 . 8 1 5}$ & $\mathbf{1 . 8 1 5}$ \\
& $\mathrm{pH} 8$ & 0.148 & 1.427 & 1.427 \\
\hline Lactose & $1 \%$ & 1.473 & 13.815 & 13.815 \\
concentration & $\mathbf{2 \%}$ & $\mathbf{1 . 5 9 6}$ & $\mathbf{1 4 . 9 6 4}$ & $\mathbf{1 4 . 9 6 4}$ \\
& $3 \%$ & 1.549 & 14.521 & 14.521 \\
\hline
\end{tabular}

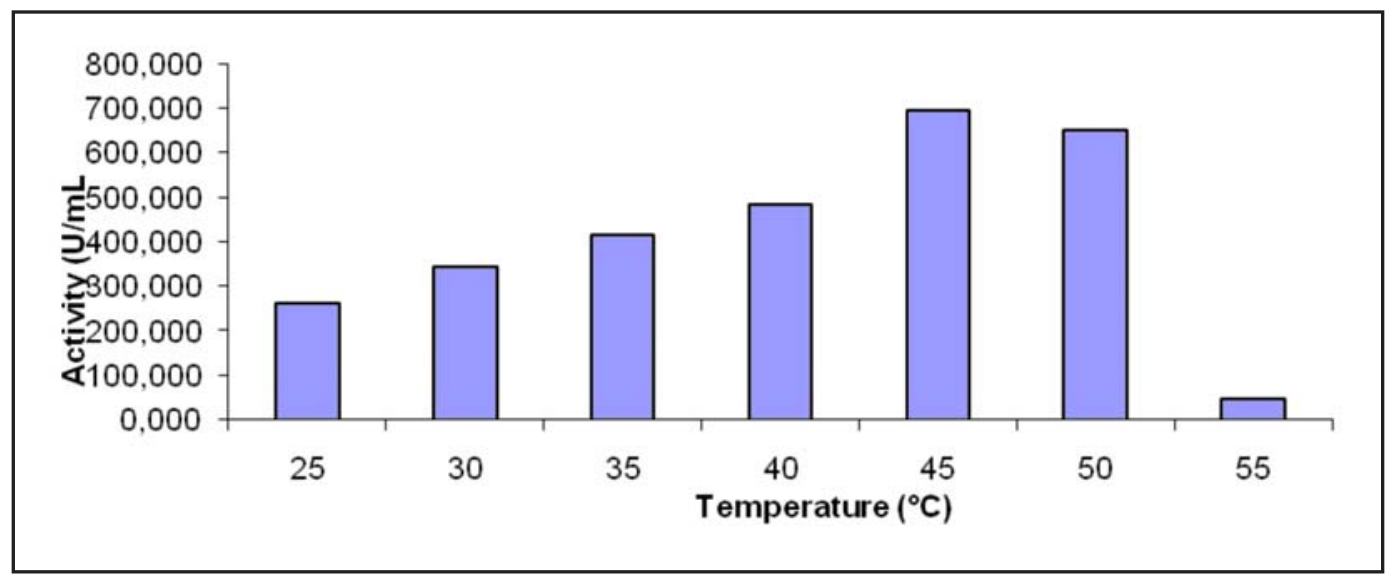

Figure 1. The $\beta$-galactosidase activities of $L$. plantarum strain B-110 in various temperatures 


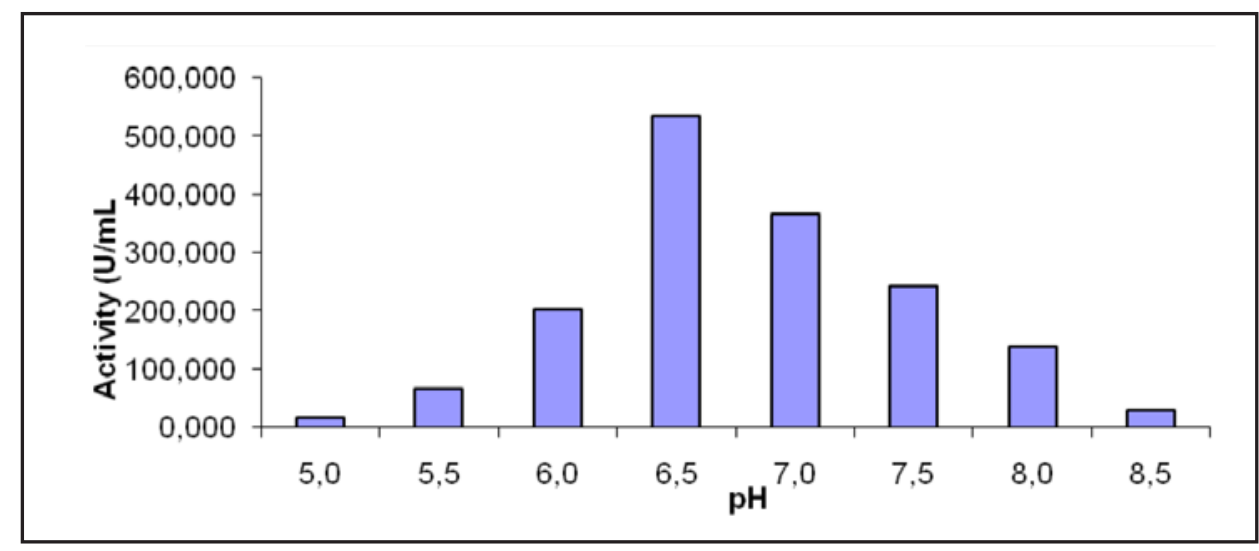

Figure 2. The $\beta$-galactosidase activities of $L$. plantarum strain $B-110$ in various $\mathrm{pH}$

Based on scrreening of the 10 (ten) out of the 70 (seventy) LAB producing $\beta$-galactosidase, $L$. plantarum strain $B 110$ was the best $L A B$ producing $\beta$-galactosidase than that of the other LAB. Furthermore, the characterization of $L$. plantarum strain B $110 \beta$-galactosidase showed that the optimum $\beta$-galactosidase production of $L$. plantarum strain B110 was reached at 30 hours incubation time, $2 \%$ inoculum concentration, medium $\mathrm{pH}: 7$, and $2 \%$ lactose concentration. Moreover, it was shown that he optimum $\beta$-galactosidase activity of $L$. plantarum strain $\mathrm{B} 110$ was reached at temperature: $45^{\circ} \mathrm{C}$ and $\mathrm{pH}: 6,5$, respectively

\section{REFERENCES}

Bai, C, and S.J. Elledge. 1996. Methods of Enzymology. No. 273: 331-347.

Britz, T.J., and R.K. Robinson. 2008. Advanced Dairy Science and Technology. UK: Blackwill Publishing Ltd.

Chakraborti, S., R.K. Sani, U.C. Banerjee, and R.C. Sobti. 2000. Purification and characterization of a novel $\beta$-galactosidase from Bacillus sp. MTCC-3088. Journal of Industrial Microbiology and Biotechnology. 24: 58-63.

Chen, W., H. Chen,Y. Xia, J. Zhao, F. Tian, and H. Zhang. 2008. Production, purification, and characterization of a potential thermostable $\beta$-galactosidase for milk lactose hydrolysis from Basillus stearothermophilus. J. Dairy Sci..91: 1751-1758

Guzek, M., M. Stojek, Wierzbowski, A. Sulkowska, and M. Smoczynski. 2008. Tolerance of low lactose milk and supplemented lactase obtained from Aspergillus oryzae in persons with lactose intolerance. Gastroenterologia Polska.15: 305-308.

Hsu, C.A., R.C. Yu, and Chou. 2005. Production of $\beta$-Galactosidase by Bifidobacteria as influenced by various culture collection. International Journal of Food Microbiology. 104: 197-206.

Jokar, A., and A. Karbassi. 2011. In-house production of lactose hydrolyzed milk by $\beta$ Galactosidase from Lactobacillus bulgaricus. J. Agr. Sci. Techn. 13: 577-584.

Rhimi, M., N. Aghajari, B. Jaouadi, M. Juy, and S. Boudebbouze. 2009. Exploring the acidotolerance of $\beta$-galactosidase from Lactobacillus delbrueckii subsp. bulgaricus: an attractive enzyme for lactose bioconversion. Res. Microbiol. 160: 775-784.

Lapage, S.P., A. Efstratiou, and L.R. Hill. 1973. The ortho-nitrophenol (onp) test and acid from lactase in gram-negative genera. Journal of dairy pathology. 26:821-852. 
Li, L., M. Zhang, Z. Jiang, L. Tang, and Q. Cong. 2009. Characterization of a thermostable family $42 \beta$-galactosidase from Thermotoga maritima. Food Chemistry.. 112: 844-850.

Lu, L.L., M. Xiao, Y.M. Li, and F.S. Wang. 2009. A novel transglycosylating $\beta$-Galactosidase from Enterobacter cloacae B5. Process Biochem. 44: 232-236.

Mahenthiralingan, E., A. Marchbank, P. Drevinek, I. Garaiova, and S. Plummer. 2009. Use of colony-based bacterial strain typing for tracking the fate of Lactobacillus strains during human consumption. BMC Microbiology. 9: 251-265.

Marteau et al. 1990. Effect of the microbial lactase (EC 3.2.1.23) activity in yoghurt on the intestinal absorption of lactase: an in vivo study in lactase-deficient humans. British Journal of Nutrition. 64: 71-79.

Mozumder, N.H.M.R., M. Akhtarruzzaman, M.A. Bakr, and M. Tuj Zahra. 2012. Study on isolation and partial purification of lactase ( $\beta$-galactosidase) enzyme from Lactobacillus bacteria isolated from yoghurt. J. Sci. Res. 4: 239-249.

Wang, D., and M. Sakakibara. 1997. Lactose hydrolysis and $\beta$-galactosidase activity in sonicated fermentation with Lactobacillus strain. Ultrasonics Chonocem. 4: 255-261. 